\title{
“Are You Ready?” Revisiting Needs Analysis for Esp Online Conversation Course
}

\author{
Noni Mia Rahmawati, noni.mia@unisma.ac.id, Universitas Islam Malang, Malang, \\ Indonesia
}

\begin{abstract}
It is common to be found in an ESP class where the students are not fully engaged in the learning activities due to their lack of interests toward English. To attract the ESP students' interests, authentic materials and meaningful activities need to be provided. Online learning can bring authentic materials to ESP students and give them meaningful activities as they can interact with native speakers of English through many online platforms. To fit the students' online learning situations to their learning experiences, as well as the materials and activities to be given, a needs analysis should be carried out. The study focuses on discovering the ESP students' preparedness in performing an online English conversation course by conducting a needs analysis. Questionnaires were given to 82 students and an interview was performed with 17 students to gain the data. The data collected in the form of percentages were analyzed by describing them qualitatively. From the analysis, it can be concluded that the ESP students were prepared to join the online English conversation course.

Keywords: English for Specific Purposes; needs analysis; online learning; English conversation; student preparedness
\end{abstract}

\section{INTRODUCTION}

Ally (2004) defines online learning as using the Internet as a media to access the materials, as well as to interact with the content, instructor and other learners for the learners to gain knowledge, to construct personal meaning, and to grow from the learning experience. Online learning is believed to convey some advantages for both teachers and students. Many believe that specialized delivery technologies, including online learning, can provide students with efficient and timely access to the materials (Ally, 2004; Setiawan, 2018). It gives flexibility to the students to access the materials everywhere and anytime so that the learning process can be performed more efficiently and effectively as, for example, the students do not have to come to the school or campus to access the materials and for collecting their assignments.

Besides providing flexibility in learning, online learning can also get hold of many students in different communities (Setiawan, 2018). There is no limitation of space that can hinder students from accessing new knowledge. Setiawan also deems that student's independence in learning is also amplified by offering them learning materials which are suitable to their needs and interests. The students, then, can match what they need to learn to their level of proficiencies. Bearing those advantages, many educators have paid closer attention to the practice of online learning, including those who are involved in English conversation or speaking

205 | IJET| Volume. 10, Issue 2. December 2021

Copyright Noni Mia Rahmawati is licensed under Creative Commons Atrribution-ShareAlike 4.0 International License. 
classes for English for Specific Purposes (ESP) students. It is common to be found in an ESP class where the students are not fully engaged in the learning activities due to their lack of interests toward English. Wu, Yen, and Marek (2011) mention that students are often not psychologically, integratively, motivated to engage in their study of English. However, Lawn and Lawn (2015) finds that some commercial online conversation programs were successful in developing business staffs' speaking proficiency in English speaking environments. The situation implies the possibility of online learning to bring better results to the learners' Englishspeaking ability.

Such results may occur since online learning can bring authentic materials to ESP students. Otero (2016) mentions some studies have shown that students can gain the outmost outcomes from innovative materials based on authentic materials and the use of ICT. Making use of ICT through online learning gives students the opportunities to obtain authentic materials of English as they can interact, directly or indirectly, with native speakers of English through many online platforms. $\mathrm{Wu}$, Yen, and Marek (2011) find that in EFL domains, technology makes it possible to provide opportunities more commonly found only when there is a surrounding population of native speakers, and thus helps transform traditionally passive learners into more engaged and interactive learners. By using ICT to have online interactions with the native speakers of English, meaningful activities that portray real-world situations can be created to give authentic experiences to the students. Hence, the students can draw an image of how English is applied in their situations.

To fit the students' learning experiences to their authentic situations, a needs analysis should be carried out. Boroujeni and Fard (2013) argue that needs analysis can be useful for identifying the goals and objectives of the learners for learning a language to determine whether or not a program should be implemented. Similarly, Ismagilova \& Polyakova (2014) describe that needs analysis is the first step to be completed to designing a syllabus, including developing materials and activities, for identifying the goals that learners would like to achieve while taking a course. The analysis should include (1) the target situation analysis, which provides information about the objectives and the skills as well as the language needed for the context in which learners will use the L2; (2) the learning situation analysis, which provides information about subjective needs; and (3) the means analysis, which provides information about the educational contexts (Benavent \& Sanchez-Reyes, 2015). It can be seen that needs analysis is crucial to be completed in ESP classes since the results of the needs analysis may serve as a guide for the teaching and learning process.

For online learning, conducting needs analysis, is very important to find the readiness of both the internal and external factors that influence the success of the learning process. The availability of Internet connections becomes the most vital external factor that decides whether virtual classes can be made or not. From observing how the online learning has been performed in Indonesia during the COVID-19 pandemic status, Fithra (2020) has discovered several problems, one of which is related to the availability and stability of the Internet connections that are different from one area to another area. Ideally, instructors need to address such differences, so that learners can get the upmost learning experiences although they are in a poor learning environment.

Many studies related to performing needs analysis for ESP students have been conducted since years ago. Boroujeni and Fard (2013) completed a study about needs analysis for ESP students in the Iranian context. The study focuses on discovering the learning needs of Iranian

206 | IJET| Volume. 10, Issue 2. December 2021

Copyright Noni Mia Rahmawati is licensed under Creative Commons Atrribution-ShareAlike 4.0 International License. 
university students to assess the implementation of CLT in ESP context. The results of the study show that the students' learning needs and styles support the adoption of CLT in ESP classes. The instructors' positive attitudes toward CLT also suggest that CLT can be applied in ESP classes. Such results show the importance of conducting needs analysis in picking up a teaching method suitable to the students. Related to online learning, Parker, Maor, and Herrington (2013) also perform a study on how needs analysis decides the steps in developing a course for higher education students. The results of the study strengthen the notion that needs analysis is significant in designing an effective and useful course for the students.

The current study attempts to investigate the preparedness of the Business Administration students of the University of Islam Malang in joining an online English conversation course by performing needs and situation analysis. It is expected that this study will give some hints on the students' needs and their situations, especially related to the availability and stability of the Internet connections. The results of this study are useful for designing the materials and activities of the online English conversation course for Business Administration students of the University of Islam Malang.

\section{METHOD}

The current study is a descriptive qualitative study. The data is collected in the forms of questionnaire and interview given to the seventh-semester students of Business Administration program of the University of Islam Malang who join an English conversation course, formally called as Percakapan Bahasa Inggris course. The questionnaire was given before the start of the course, and the gained data was calculated to be described. The data obtained from the questionnaire was strengthened by performing an interview with several students who were randomly selected. The data from the interview was also to be described.

The questionnaire consisted of 36 questions which were divided into three sections. The first section had four questions that deals with the students' data. The second section consisted of 16 questions about the students' perceptions of doing online classes in general. Another 16 questions in the third section were asking the students' opinions on performing an online English conversation course. The questionnaire was in the form of multiple choices and was given to the students through an online form. The data attained from the answers of each question was automatically calculated by the online form into percentages. Then, the data was analyzed by describing the earned percentages of each question.

After the data from the questionnaire was obtained, an interview was performed. The questions given in the interview were related to the questions presented priorly in the questionnaire. The interview was carried on after the fourth meeting of Percakapan Bahasa Inggris course. The interview was performed simultaneously among the students through a video conference due to the COVID-19 pandemic situation. There were seven questions given to the students with some additional questions as a response to the students' answers to each question. The interview was recorded, and the analysis was completed by describing the students' answers to the questions.

\section{RESULT}

207 | IJET| Volume. 10, Issue 2. December 2021

Copyright Noni Mia Rahmawati is licensed under Creative Commons Atrribution-ShareAlike 4.0 International License. 
The results of the study were obtained from the questionnaire given to and the interview performed with the seventh-semester students of Business Administration program of the University of Islam Malang who join the Percakapan Bahasa Inggris course. 82 students participated in answering the questions given in the questionnaire, and 17 students participated in the interview.

\section{The Questionnaire}

The questionnaire was divided into three sections in the forms of statements with multiple choices in Bahasa Indonesia. There were four choices for each statement which ranged from (1) strongly agree; (2) agree; (3) disagree; and (4) strongly disagree.

\section{The First Section of the Questionnaire}

This section was about the students' personal information about the (1) students' gender; (2) students' age; (3) time they spent using the gadgets they have for learning, online and offline, within a week; and (4) time they spent online within a week, either for learning or any other purposes. From the respondents, $79.3 \%$ were female. and $20.7 \%$ were males. $91.5 \%$ were between 18 and 22 years old, and only $8.5 \%$ of them were between 23 and 27 years old. Within one week, most of the students spent one to five hours using their gadgets, either online or offline, with $47.6 \%$ of the respondents chose the answer. Only $7.3 \%$ of the students who spent more than ten hours per week to use their gadgets for learning. As for going online for any purposes they have, there was no big difference in percentages among the four answers provided with (1) $32.9 \%$ of the students answered they go online for one to five hours; (2) $30.5 \%$ for more than ten hours; (3) $23.2 \%$ for six to ten hours; and (4) $13.4 \%$ for less than one hour. From the results in this section, it can be seen that the students are familiar with operating the applications they have in their gadgets as they spend enough times operating their gadgets either offline or online for any purpose they have.

\section{The Second Section of the Questionnaire}

The section dealt with some statements related to performing online learning in general. Among 16 numbers, the statements could be grouped into statements associated to (1) the availability and the ability to use the Internet; (2) the students' comfort to communicate online among peers or with the lecturers; (3) the students' learning style; (4) the students' dependence on the lecturers; and (5) the students' motivation in doing online learning. Positive responses given for the questions in this section show that the students are prepared in performing online classes.

About the availability of the Internet connection, $18.3 \%$ of the students answered that they could not access the connection easily, and $2.4 \%$ of them believed that it was very difficult for them to access the Internet. Meanwhile, there were $84.1 \%$ of the students who thought that they were skilled enough in running the applications in their computer and gadgets.

208 | IJET| Volume. 10, Issue 2. December 2021 


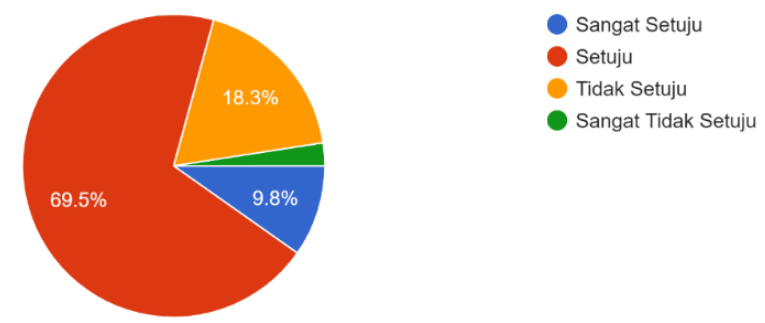

\section{Image 1. The Availability of the Internet Connection}

Related to the students' comfort to communicate online among peers and with the lecturers, $52.4 \%$ of the students mentioned that they were comfortable and $20.7 \%$ of them regarded that they were very comfortable to communicate online through Social Networking Sites (SNSs), such as WhatsApp, Instagram, etc. However, there were $24.7 \%$ of the respondents who believed that it was not comfortable for them to do online communication through such networking sites. Still, $74.4 \%$ of the students were willing to communicate actively with their peers and lecturers during their online classes, especially through text messages as $59.8 \%$ of them agreed that it was comfortable for them to have written communication.

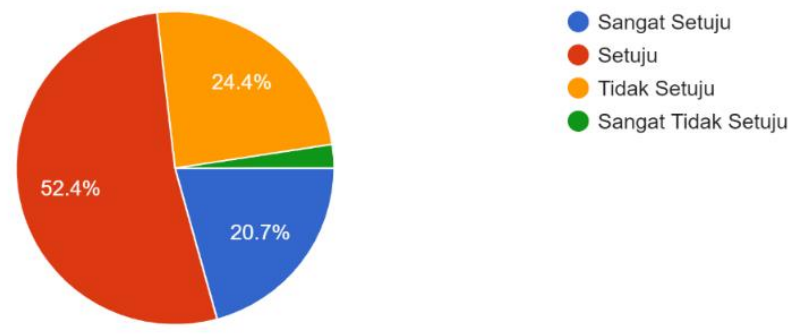

\section{Image 2. The Students' Comfort to Communicate Online}

The results that show the students' comfort in performing online communication correspond to the students' comfort in communicating during their online classes. Blakenship and Atkinson (2010) deem that the students are comfortable with non-face-to-face communication now as a result of the background and experience which is beneficial to their studies. Having sufficient background and experience in using the Internet give the students' the familiarity and comfort they need to perform their online classes. Such comfort drives the students to be willing to more actively communicate with their peers and lecturers, especially through text messages.

Concerning the students' learning style, $61 \%$ of the students thought they can understand a lesson better when they can go over the materials given to them. $68.3 \%$ of the students believed they were disciplined enough in performing independent learning, and $74.4 \%$ of them mentioned they can arrange their time effectively in learning and completing their assignments on time. About whether the students prefer to work individually or in groups when they learn a lesson or complete an assignment, $48.8 \%$ of them prefer working individually, and $72 \%$ of the students mentioned they like to be working in groups. Such results occurred as the students' background and experience also facilitate them with their self-management of learning (Blakenship and Atkinson, 2010).

About the students' dependence on the lecturers, $54.9 \%$ of the students agreed and $15.9 \%$ strongly agreed that their lecturers give them fast response when they ask something to the

209 | IJET| Volume. 10, Issue 2. December 2021

Copyright Noni Mia Rahmawati is licensed under Creative Commons Atrribution-ShareAlike 4.0 International License. 
lecturers online beyond the classes. Still, $61 \%$ of the respondents agreed and $36.6 \%$ of them strongly agreed that the students need to have face-to-face classes with the lecturers, either offline or through video conferences. Given the statement about if it was acceptable not to see the lecturers and their peers face-to-face, $48.8 \%$ of the students agreed that it was acceptable, while $35.4 \%$ of them disagreed of it. These results show that although the students suppose that they have good self-management of learning, they still need to have real-time communications with the lecturers to help them understand the materials.
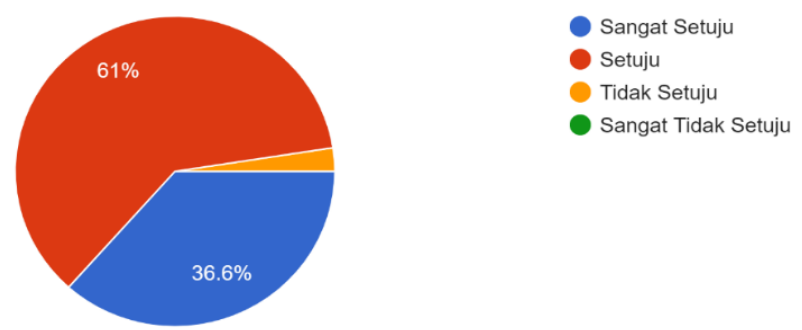

\section{Image 3. The Students' Needs on Face-to-Face Classes}

For the last group of questions about the students' motivation in doing online learning, $53.7 \%$ of the students agreed that the availability of the materials to be accessed anytime makes them motivated to learn. However, $72 \%$ of the students and $17.1 \%$ of them disagreed and strongly disagreed with the statement that there is no difference between online learning and offline learning. Still, $70.7 \%$ of the students believed that they can pass a subject in an online class similarly as passing a subject in an offline class.

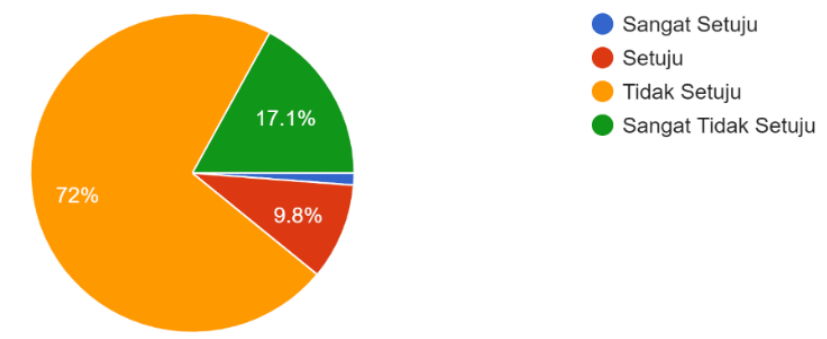

\section{Image 4. The Students' Believes that Online and Offline Learning are Similar}

\section{The Third Section of the Questionnaire}

The section was focusing on the students' ideas on performing an online English conversation course, named the Percakapan Bahasa Inggris. The questions in this section were mostly similar to those in the second section. Some differences are related to the online platforms to be used and activities to be performed in the online classes of the English conversation course. The following results related to the questions in the third section are aiming to describe the online platforms to be used and the activities to be performed in the online English conversation classes.

Related to the online platforms to be used in the online English conversation course, $61 \%$ of the students agreed and $20.7 \%$ of them strongly agreed that it is more comfortable to converse through text messages than through video conferences in performing the online Percakapan Bahasa Inggris classes. $63.4 \%$ of the students were reluctant to often have video conferences to 
perform the classes. Yet, $75.6 \%$ of them agreed to have the video conferences once in several weeks.
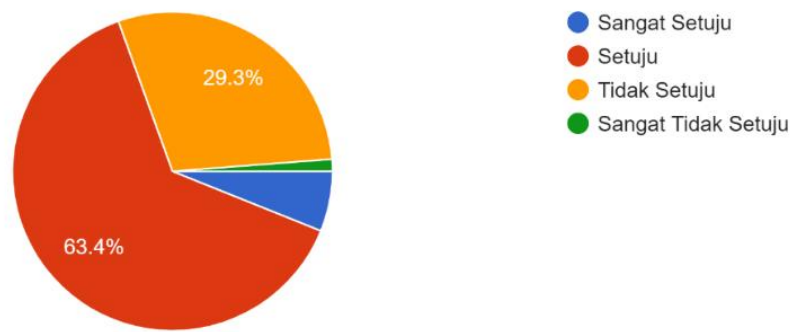

\section{Image 5. The Students' Reluctance in Often Doing Video Conferences}

An equally divided percentage obtained when the students stated if they feel to be more confident to converse in English through video conferences compared to when they have to converse offline inside the classes. $48.8 \%$ of the students did not seem to be confident to speak in English through video conferences. Meanwhile, $42.7 \%$ of them thought that they will be more confident to communicate orally in English through video conferences compared to when they need to converse offline in the classes.

For the activities to be performed, $51.2 \%$ of the students mentioned that they were reluctant when they have to do assignments in the forms of either video or audio recordings, and $9.8 \%$ of them unwilling to do so. The reason for such notion was that $57.3 \%$ of the students believed that they are not skilled enough create video or audio recordings, and $28 \%$ of them thought that they do not have the skill to make such recordings. $67.1 \%$ of the students predicted that while they will be fine with performing most of their classes online, they will encounter many difficulties when they join the online English conversation course. Moreover, 12.2\% of them strongly agreed that there will be many challenges for them in performing online English conversation classes.
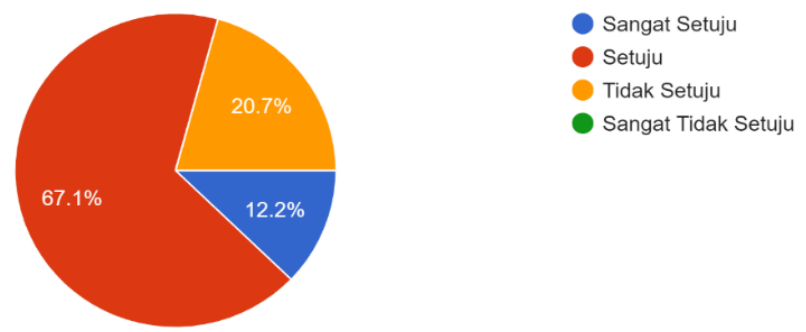

\section{Image 6. The Challenges in the Online English Conversation Course}

\section{The Interview}

The interview was comprised of seven questions given to 17 students. The interview was conducted through a video conference after the fourth meeting of the online English conversation course had been completed. The questions given to the students were related to the questions given in the questionnaire as the interview was intended to strengthen the data obtained from the questionnaire. Three questions were about online learning in general, and the other four questions were related to the online English conversation class or the Percakapan Bahasa Inggris class.

211 | IJET| Volume. 10, Issue 2. December 2021

Copyright Noni Mia Rahmawati is licensed under Creative Commons Atrribution-ShareAlike 4.0 International License. 
The first question was about the numbers of kinds of applications that the students have in their gadgets. Four students answered the questions and gave their opinions about it. Among the four students, three of them mentioned that the numbers of applications they had in their gadgets were mostly applications for Social Networking Services (SNSs) and applications for fun activities, such as games and video editing applications. Only one of them answered to have learning applications the most than other kinds of applications in her gadget. However, two students described that their online classes also make use of SNSs applications to be the online platforms to deliver the learning materials and to do the learning activities. One of the four students added that the video editing applications are also useful to support their learning activities as they are assigned to make videos more than before for their online classes.

The second question focused on comparing the interactions between lecturers and students in online classes and offline classes. Seven students gave their opinions on the matter. All of them believed that communicating in offline classes with their lecturers to be more effective in delivering their messages. The stability of the Internet connection became the main reason for them to think so. One of them added that the lecturers' way of communicating in the online classes also become a factor to have a comfortable interaction with the students. Yet, three out of the five students said that they became more active in the online classes than in the offline classes as they can focus more on performing the learning activities. They are more willing to have interactions with the lecturers in the forms of asking or answering questions as they were less anxious in the online classes than in the offline classes.

For the third question, the students were asked about their dependence toward the explanations given by the lecturers in understanding the learning materials provided for them. Three students participated in responding to the questions, of which all of them described that they still need to get explanations from their lecturers in understanding the lesson. Offline interactions, once again, were preferred by the students as they can get the explanations directly from the lecturers without further ado. They thought that such face-to-face interactions made them able to grasp the explanations from the lecturers better than the explanations they have in online classes, especially when the interactions are via text messages.

The fourth question was given to clarify the students' answers on two questions previously delivered in the questionnaire about their reluctance for often doing video conferences for the online English conversation classes. Unlike the most answers obtained from the questionnaire, eight students who gave their ideas about it mentioned that they did not mind having video conferences often for the Percakapan Bahasa Inggris class. One reason agreed by the eight students was that they can practice to speak and pronounce the words in English directly, as well as to train themselves to speak in front of the public. Such situation is in line with Wu, Yen, and Marek (2011) who believe that motivation, confidence, and ability as the learning variables are the results of the cumulative experiences of the student, both in and out of the classroom. As the interview was conducted after the fourth meeting of the course, the students had had some experiences of doing video conferences for the course, thus, they had more motivation, confidence, and ability to do the activities performed during the video conferences. Yet, when an additional question was asked to them about comparing between conversing in English through video conferences and text messages, three of them said that it was also important to converse in English through text messages. Some reasons for their opinions were (1) they can add their English vocabularies; (2) they can have more chances to

212 | IJET| Volume. 10, Issue 2. December 2021 Copyright Noni Mia Rahmawati is licensed under Creative Commons Atrribution-ShareAlike 4.0 International License. 
join the conversation in the class; and (3) they became less shy to participate through text messages.

For the fifth question, the students were asked if they find any difficulty in creating videos or audio recordings for their assignments as a part of their learning activities. Yükselir and Kömür (2017) believe that the use of audio-visual tools enables students to practice what they have learned through various techniques and to promote language learning. Five students participated in giving their opinions. All of them said that they encountered difficulties in completing such assignments since they were not skilled enough to do video or audio editing. However, they said that the challenges they found made them eager to find ways to solve the problems, thus, they were willing to be given such assignments for the online English conversation course. Such response is in accordance with Parkes et al. (2014) who find that the students were commonly considered to have high levels of preparedness for competencies associated with the use of technology and the Internet. Therefore, although the students encountered difficulties with the audio-visual assignments, they agreed to be given such assignments. They also added that it was not a problem for them to work together in pairs or groups in completing the assignments although they have to work long distance.

The sixth question was delivered to confirm the students' opinion about performing the Percakapan Bahasa Inggris course via online platforms. The focus of the question was if performing online English conversation class would be more difficult than joining other online classes. Four students believed that before the start of the online English conversation class, they predicted that they might find more challenges in the Percakapan Bahasa Inggris class than in other online classes that they join this semester. Some of their reasons were (1) being afraid that they have to constantly speak in English; (2) being shy to have to speak in English in front of other friends; and (3) being not acquainted with the lecturer of the course. However, one of the four students mentioned an advantage of performing the English conversation class online was that he can build his confidence in speaking English since it seemed he did not have to speak in front of many people at the same place.

The last question was about the kinds of topics the students wanted to have in the online English conversation class. From the interview, the first topic that the students wanted to have in the class was about practicing to speak in formal situations at work, such as leading a meeting, etc. Secondly, the students also wanted to practice their skills in written communication as they believed that they might have to communicate through letters or emails when they work.

\section{CONCLUSION}

As far as the researcher can find, the current study is different from most of the previous studies on the students' preparedness in joining online learning as it describes the data qualitatively. From the students' responds recorded in the questionnaire and the interview, it can be supposed that the students are prepared in joining online courses, including the online English conversation course. Yet, there is an aspect that should be improved that is the students' ability in completing the assignments if the assignments are in the forms of videos or audios. Of course, the stability of the Internet connection still becomes an issue, but not for the majority of the students. This study needs to be perfected by further researchers as due to the pandemic situation, the interview could not be done one-by-one with the students.

213 | IJET| Volume. 10, Issue 2. December 2021

Copyright Noni Mia Rahmawati is licensed under Creative Commons Atrribution-ShareAlike 4.0 International License. 


\section{REFERENCES}

Ally, M. (2004). Foundations of Educational Theory for Online Learning. in T. Anderson \& F. Elloumi (Eds.), Theory and Practice of Online Learning (pp. 3-31). Athabasca: Athabasca University.

Benavent, G.T. \& Sánchez-Reyes, S. (2015). Target Situation as a Key Element for ESP (Law Enforcement) Syllabus Design. Procedia - Social and Behavioral Sciences, 173, 143-148. https://doi.org/10.1016/j.sbspro.2015.02.044

Blakenship, R. \& Atkinson, J.K. (2010). Undergraduate Student Online Learning Readiness. International Journal of Education Research, 5(2): 44-54, (https://www.researchgate.net/publication/285098517_Undergraduate_student_online_lear ning_readiness, accessed on November 10, 2020).

Boroujeni, S.A. \& Fard, F.M. (2013). A Needs Analysis of English for Specific Purposes (ESP) Course for Adoption of Communicative Language Teaching: (A Case of Iranian First-Year Students of Educational Administration). International Journal of Humanities and Social Science Invention, 2(6): 35-44, (http://ijhssi.org/papers/v2(6)/Version-3/H0263035044.pdf, accessed on August 7, 2020).

Fithra, H. (2020). Covid-19 dan pembelajaran Daring. Media Indonesia. (https://mediaindonesia.com/read/detail/298964-covid-19-dan-pembelajaran-daring, accessed on May 19, 2020).

Ismagilova, L.R. \& Polyakova, O.V. (2014). The Problem of the Syllabus Design within the Competence Approach Based on the Course "English for Master Degree Students in Economics (Advanced Level)". Procedia - Social and Behavioral Sciences, 152. 10951100. https://doi.org/10.1016/j.sbspro.2014.09.281

Lawn, M.J. \& Lawn. E. (2015). Increasing English Communicative Competence through Online English Conversation Blended e-Learning. International Journal of Information and Education Technology, 5(2): 105-112. DOI: 10.7763/IJIET.2015.V5.485

Otero, R.G. (2016). Innovative resources based on ICTs and authentic materials to improve EFL students' communicative needs. New Perspectives on Teaching and Working with Languages in the Digital Era, 2016, 83-93. https://doi.org/10.14705/rpnet.2016.tislid2014.424

Parkes, M., Stein, S., \& Reading, C. (2015). Student preparedness for university e-learning environments. Internet and Higher Education, 25(April), 1-10. https://doi.org/10.1016/j.iheduc.2014.10.002

Setiawan, Y. (2018). Pemanfaatan Kelas Maya untuk Pembelajaran Daring. Jakarta: Kementrian Pendidikan dan Kebudayaan.

Wu, W.V., Yen, L.L., \& Marek, M. (2011). Using Online EFL Interaction to Increase Confidence, Motivation, and Ability. Educational Technology \& Society, 14(3): 118-129, (https://www.jstor.org/stable/pdf/jeductechsoci.14.3.118.pdf?seq=1, accessed on August 7, 2020).

214 | IJET| Volume. 10, Issue 2. December 2021

Copyright Noni Mia Rahmawati is licensed under Creative Commons Atrribution-ShareAlike 4.0 International License. 
Yükselir, C. \& Kömür, Ş. (2017). Using Online Videos to Improve Speaking Abilities of EFL Learners. European Journal of Education Studies, 3(5). 255-266. https://doi.org/10.5281/zenodo.495750 